\title{
Residual Trees Response to Selective Cutting Operations in Caspian Forests
}

\author{
Farshad Keivan Behjou, Alireza Ghomi Motazeh
}

\begin{abstract}
Nacrtak
Damages to residual trees caused by felling operation were assessed in the stands of a Caspian hardwood forest. Following the felling operation, a field survey was done to collect data of all residual trees (species, DBH, height) and of tree wounds (size class, location, intensity of damage). Different harvesting intensities were studied, and treatments were replicated three times. The results showed that the treatment with the medium and high harvest intensity was found to cause the highest percentage of damage and the largest stem wounds. It is concluded that harvesting intensity should be limited to 3 trees/ha during each harvesting operation to reduce the extent of tree damage and thus future financial loss.
\end{abstract}

Keywords: tree damage, felling operation, Caspian forests

\section{Introduction - Uvod}

The trees in northern forests of Iran are felled by chainsaws, approximately 1.9 million hectares being commercial forests called Caspian forests, Hyrcanian or Northern forests (Limaei and Lohmander 2007). The commercial forests are located in the northern part of Iran, between north of the Alborz Mountain and south of Caspian Sea (Bahjou 2013). These forests are uneven-aged structures of varying species such as: beech (Fagus orientalis), hornbeam (Carpinus sp.), maple (Acer sp.), oak (Quercus sp.) (Limaei and Lohmander 2007). The type of forest management system is selection method (Marvimohajer 2006). In Iran, industrial logging occurs only in the Caspian forests. High quality hardwood saw-timber is harvested in these forests, but in addition to timber production, these forests must be managed to produce a variety of non-timber goods such as flora, fauna, water, and aesthetic experience (Holmes et al. 2002, Marvimohajer 2006). Due to the higher initial costs of harvesting machines, larger diameters and crowns of hardwoods and a relatively steep train in Caspian forests, motor manual harvesting and a wheeled skidder are still the most commonly used system in this region (Behjou et al. 2008). Each of these machines can cause distinct damage to residual trees. The majority of residual trees are locat- ed along skid trails where most harvesting activity occurs (Solgi and Najafi 2007). Due to these injuries, trees are threatened by fungous infections. The extent of this threat depends on the size and position of the injuries as well as on tree species (Dvorak 2005). The injuries also negatively affect the increment of certain trees (Dvorak 2005). Wounding can cause stem deformity and decay and significantly affect final crop volume and value (Solgi and Najafi 2007). Smith et al. (1994) indicated that sapwood wounds pose no immediate threat to the tree but increase the likelihood of attack by insects or diseases. Stern decay is the major cause of low-quality wood. The amount of decay development is related to the time since injury, size of wound, tree species, location of wound on the tree, and trees vigor. Fajvan et al. (2002) found that the 12inch diameter-limit harvest had the highest percentage of damage and largest stem wounds in comparison to the 16in. diameter-limit harvest and an establishment cut of the shelter-wood method. Other researchers have found that the occurrence of logging wounds is independent of harvest intensity (Nyland and Gabriel 1971, Reisinger and Pope 1991).

Residual stem damage is also directly correlated with the skills and attitude of the logging contractor and machine operator (Smith et al. 1994, Reisinger and Pope 1991), the season of harvest (Aho et al. 1983) 
and site variables (Cline et al. 1991). Naghdi (2004) found that about $1.4 \%$ of trees along skid trails were damaged or destroyed by felling operation in Caspian forests. During the felling operation, it is important to minimize the damage to residual trees so as to maintain stand vigor and timber quality (Fajvan et al. 2002). Nikooy (2007) indicated that about $1.9 \%$ of residual trees receive one type of damage during felling operation in Caspian forests. Physical damage to roots and boles can result in loss of vigor and growth reduction to trees that may have benefited from reduced competition (Shigo 1985). Damage to residual trees can also reduce timber value because of volume loss caused by wood discoloration or decay. The size and severity of the wound, time since injury, and type of species damages are directly correlated with the amount of decay (Hesterberg 1957, Shigo 1979). Damaged trees are also more susceptible to radial and ring shakes, especially in oaks (Fajvan et al. 2002). Dvorak (2005) found that the percentage of injured trees in individual age classes ranged from 1.5 to $2.38 \%$ in mountain areas. Behjou (2014) assessed the effects of wheeled cable skidding on residual trees following selective logging in Caspian Forests, and the results prove that most common types of damage were stem wounds to the cambium layer and bark scrapes. In the current study, comparisons were made among three different harvest intensities and stand densities. The objective of this study is to investigate damages to residual trees by felling system and determine the influence of stand density and harvest intensity during felling operation.

\section{Materials and methods Materijal $i$ metode}

\subsection{Study area - Područje istraživanja}

Three study areas were selected in the Caspian forests in the North of Iran. Each study area was divided into three 10 ha treatment blocks. Each 10 ha treatment area included one harvest intensity treatment: 3.04, 5.11, and 6.52 trees per hectare, for a total of three replications. The forest type is classified as temperate mixed-hardwood forests (Marvimohajer 2006). The sites had northern aspects, well drained soils, and steeply sloping train with slopes $>25 \%$. The over-story canopy basal area was dominated by beech (Fagus orientalis), hornbeam (Carpinus sp.), maple (Acer sp.) and alder (Alnus subcordata). After felling $2050 \mathrm{~m}^{3}$ of timber in three compartment areas in April 2015, the study was done immediately.

\subsection{Field procedures - Terenski postupci}

To assess the damages to residual trees, a $100 \%$ survey was conducted after felling operations. All damaged trees greater than $10 \mathrm{~cm}$ DBH within $4 \mathrm{~m}$ of the skid trail centerline were labeled and the types of damage were recorded. Stems were classified as either (1) uninjured, (2) injured, (3) destroyed. Damages to residual trees were recorded according to the location and severity of the wound (Krueger 2004). Also, damage assessment procedures were similar to those used in other studies (Fajvan et al. 2002, Nichols et al. 1994, Krueger 2004, Jackson et al. 2002). Table 1 shows the characteristics of study areas.

Each stem wound of injured trees was categorized by the longest and widest dimensions of the wound, location on the stem, and wound severity. In a similar manner, root wounds were measured and assessed on uprooted, exposed and damage cambial tissue, and exposed cambial tissue but no damage, root scrape. Wound severity was classified as either a scuff (bark scraped but intact), a scrape (but scraped off and wood exposed), or a gouge (lacerated exposed wood). Combination wounds (e.g. a scrape within a scuff) were noted and each type was measured separately.

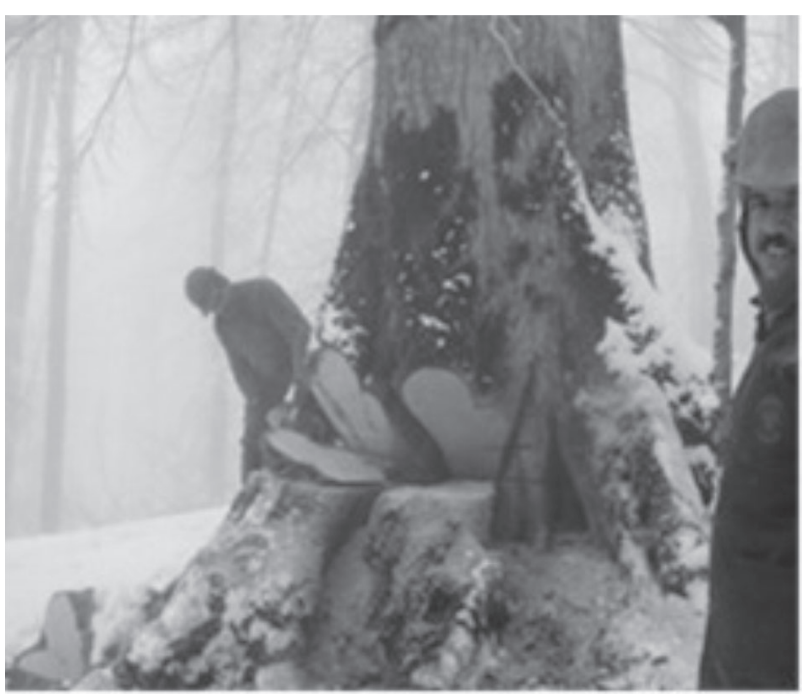

Fig. 1 Cutting operation

Slika 1. Operacija sječe

The distance of residual trees to the nearest skid trail was measured from the middle of the tree bole to the closest tire track of a primary, secondary, or tertiary skid trail. In primary skid trails, more than ten trees had been skidded, in secondary skid trails 2-10 trees had been skidded, and in tertiary skid trails one tree had been skidded (Jackson et al. 2002). 


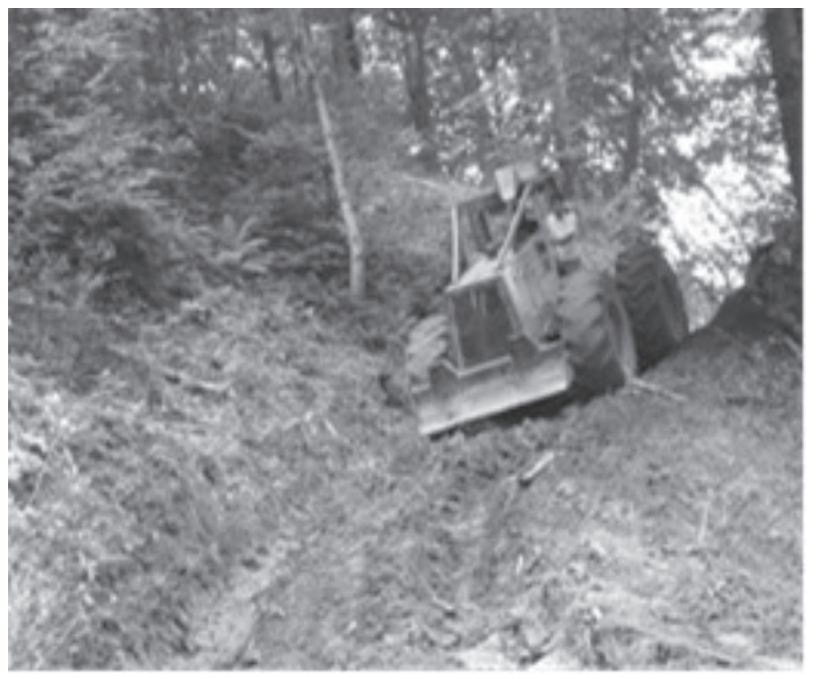

Fig. 2 Skidding trail

Slika 2. Traktorska vlaka

\subsection{Data analysis - Analiza podataka}

Analysis of variance (ANOVA) was used to examine differences in residual stand structure (basal area, trees per hectare and stand diameter) among treatments. In order to account for treatment differences that may result from differences in pre-harvest stand density (Table 1), an analysis of covariance (ANCOVA), with the pre-harvest basal area as the covariate, was used to test for treatment differences.

Pre-harvest basal area did not significantly improve the ANCOVA model; therefore, a randomized block ANOVA was used to determine treatment differences in wound size. Dependent variables were the total area damaged per tree (square centimeter) and a ratio of wound width to tree circumference (wound-stem ratio). The wound-stem ratio was used to compensate for the greater impact of a large wound on a small tree versus the same size wound on a large tree. Wound size and ratio values were $\log 10$ transformed. Basal area values were square root transformed. Logistic regression was used to develop a probability model for estimating occurrence of residual stem damage based on pre-harvest and post-harvest tree, stand, and harvest attributes
(Nichols et al. 1994, Fajvan et al. 2002). The outcome of damage to each stem is binary (damaged or undamaged). The STEPWISE logistic regression procedure in the SAS statistical software package was used to develop the final damage model. The probability of a tree being damaged during harvest is expressed as a continuous function with the form of the logistic model:

$P\left(Y_{i}=1\right)=\left[1+\exp \left(-\left(B_{0}+B_{1} X_{1}+\cdots+B_{n} X_{n}\right)\right)\right]^{-1}$

Where:

$P$ probability

$Y_{i} \quad 1$ if undamaged, 0 if damaged

$B_{i} \quad$ estimated regression parameters

$X_{i} \quad$ variables influencing residual tree damage

The following independent variables were considered to develop the model: DBH, stand density (pre-harvest and post-harvest trees per hectare), basal area per hectare, harvest intensity (marked trees per hectare), and distance of stem from skid trails. The logistic model was run for each treatment and a P value of 0.1 was used as the inclusion criteria for variables in the model. Destroyed trees were not included in the model because it was difficultimpossible to measure post-harvest stem attributes. The percentages of damage were combined into two classes: (1) no damage, (2) damaged.

\section{Results - Rezultati}

Most of the basal area removed in each treatment consisted of beech and alder. These species comprised $87 \%$ of the basal area removed from the first treatment, $58 \%$ removed from the second treatment, and $89 \%$ removed from the third treatment. The mean residual trees per hectare $(\geq 10 \mathrm{~cm})$ were similar in three compartments (treatments) according to the Duncan multiple range test (Table 1). Out of 334 residual trees, 194 received some type of damage by felling.

Wound size on the root and but was significantly larger in the second treatment $(\mathrm{P}=0.003)$, but the woundstem ratio was similar among treatments (Table 2).

Table 1 Compartment properties in the study area

Tablica 1. Karakteristike odjela na području istraživanja

\begin{tabular}{|c|c|c|c|c|c|c|}
\hline $\begin{array}{l}\text { Compartment } \\
\text { Odjel }\end{array}$ & $\begin{array}{c}\text { Area, ha } \\
\text { Površina, ha }\end{array}$ & $\begin{array}{l}\text { Dominant tree species } \\
\text { Dominantne vrste }\end{array}$ & $\begin{array}{c}\text { Stand density, trees/ha } \\
\text { Broj stabala, N/ha }\end{array}$ & $\begin{array}{l}\text { Growing stock, } \mathrm{m}^{3} \\
\text { Drvna zaliha, } \mathrm{m}^{3}\end{array}$ & $\begin{array}{l}\text { Number of marked trees } \\
\text { Broj doznačenih stabala }\end{array}$ & $\begin{array}{l}\text { Harvest intensity, trees/ha } \\
\text { Intenzitet sječe, stabala/ha }\end{array}$ \\
\hline 228 & 42 & Fagus orientalis, Carpinus sp. & 164 & 225.9 & 190 & 3.04 \\
\hline 231 & 66 & $\begin{array}{l}\text { Fagus orientalis } \\
\text { Alnus subcordata }\end{array}$ & 175 & 175 & 552 & 5.11 \\
\hline 232 & 48 & Fagus orientalis, Carpinus sp. & 176 & 267.3 & 281 & 6.52 \\
\hline
\end{tabular}


Table 2 Mean wound size and wound-stem ratio (standard error) on the root and butt

Tablica 2. Srednja veličina oštećenja i odnos oštećenje - deblo (standardna pogreška) na korijenu i žilištu

\begin{tabular}{|c|c|c|c|}
\hline $\begin{array}{c}\text { Treatment } \\
\text { Tretman }\end{array}$ & $\mathrm{N}$ & $\begin{array}{c}\text { Wound size, } \mathrm{cm}^{2} \\
\text { Veličina oštećenja, } \mathrm{cm}^{2}\end{array}$ & $\begin{array}{c}\text { Wound stem ratio } \\
\text { Odnos oštećenje - deblo }\end{array}$ \\
\hline 1 & 3 & $541(104)^{\mathrm{a}}$ & $9(4)$ \\
\hline 2 & 3 & $398(111)^{\mathrm{b}}$ & $4(2)$ \\
\hline 3 & 3 & $522(123)^{\mathrm{a}}$ & $4(2)$ \\
\hline $\begin{array}{c}\mathrm{p} \text {-value } \\
\text { p-vrijednost }\end{array}$ & $0.004^{* *}$ & $0.04^{*}$ \\
\hline
\end{tabular}

${ }^{* *}$ Significant at alpha $\leq 0.01-$ Značajno kod alfa $\leq 0.01$
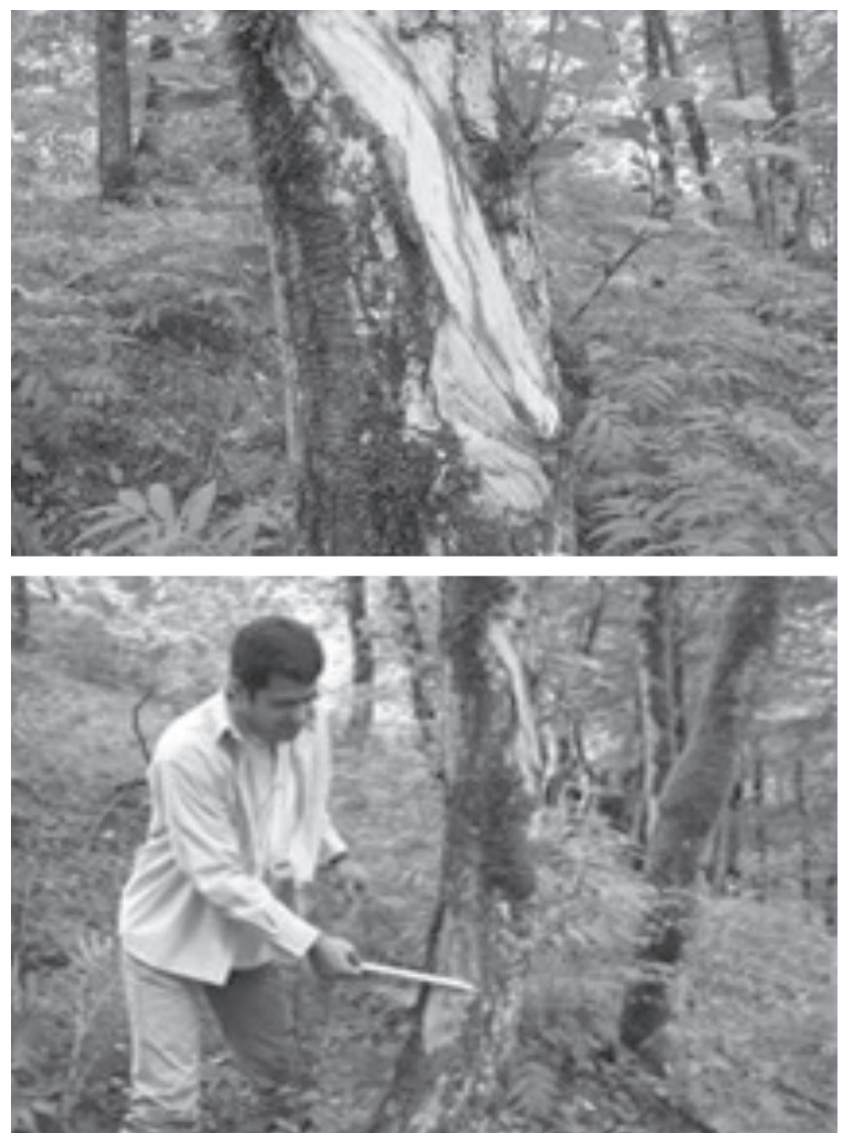

Note: The same letter within columns means that there is no significant difference according to Duncan multiple range test

Napomena: Jednake slovne oznake u stupcu označavaju da nema značajne razlike prema Duncanovu testu

The average size of a scuff, scrape, and gouge was significantly larger in the second treatment (Table 3). The wound-stem ratio of a scrape was similar among treatments, but the wound-stem ratio of a scuff and gouge were larger in the second treatment (Table 4). In the second treatment, root and but damage of $87 \%$ of all residual trees was $>100 \mathrm{~cm}^{2}$, while in the first treatment, the wounded area of $79 \%$ of damaged trees was in excess of $100 \mathrm{~cm}^{2}$.
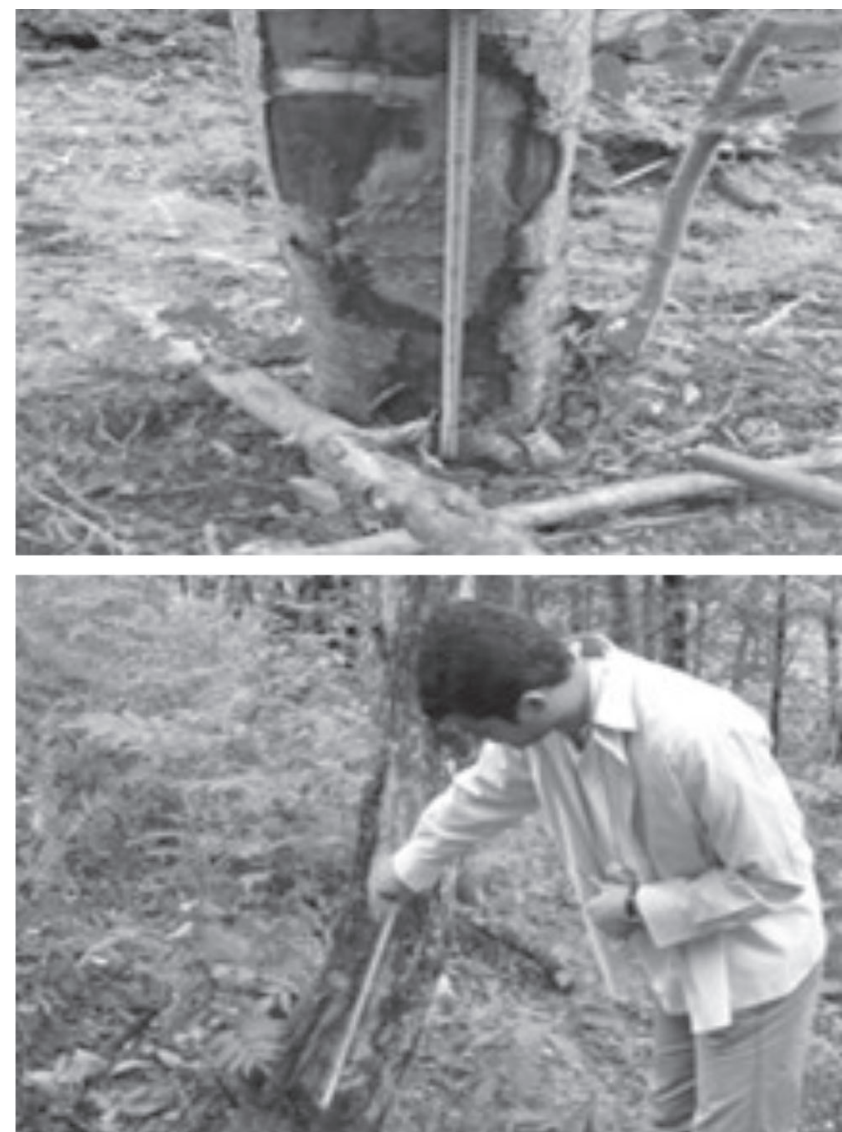

Fig. 3 Kinds of wounds and their measurement

Slika 3. Vrste oštećenja i njihova izmjera

Table 3 Mean wound size and wound-stem ratio (standard error) on the root and butt

Tablica 3. Srednja veličina oštećenja i odnos oštećenje - deblo (standardna pogreška) na korijenu i žilištu

\begin{tabular}{|c|c|c|c|c|c|c|c|}
\hline $\begin{array}{c}\text { Treatment } \\
\text { Tretman }\end{array}$ & $\mathrm{N}$ & \multicolumn{3}{|c|}{$\begin{array}{c}\text { Wound size } \\
\text { Veličina oštećenja }\end{array}$} & \multicolumn{3}{c|}{$\begin{array}{c}\text { Wound stem ratio } \\
\text { Odnos oštećenje-deblo }\end{array}$} \\
\hline & & $\begin{array}{c}\text { Scuff } \\
\text { Ogrebano }\end{array}$ & $\begin{array}{c}\text { Scrape } \\
\text { Oguljeno }\end{array}$ & $\begin{array}{c}\text { Gouge } \\
\text { Udubljeno }\end{array}$ & $\begin{array}{c}\text { Scuff } \\
\text { Ogrebano }\end{array}$ & $\begin{array}{c}\text { Scrape } \\
\text { Oguljeno }\end{array}$ & $\begin{array}{c}\text { Gouge } \\
\text { Udubljeno }\end{array}$ \\
\hline 1 & 3 & $94(44)^{\mathrm{a}}$ & $406(95)^{\mathrm{a}}$ & $29(11)^{\mathrm{a}}$ & $8.2(2)^{\mathrm{a}}$ & $16.3(4)^{\mathrm{a}}$ & $5.3(1.6)^{\mathrm{a}}$ \\
\hline 2 & 3 & $345(99)^{\mathrm{b}}$ & $177(77)^{\mathrm{b}}$ & $89(6)^{\mathrm{b}}$ & $9.1(4)^{\mathrm{a}}$ & $9.4(3)^{\mathrm{b}}$ & $9.1(0.5)^{\mathrm{b}}$ \\
\hline 3 & 3 & $409(35)^{\mathrm{b}}$ & $501(133)^{\mathrm{a}}$ & $76(11)^{\mathrm{b}}$ & $3.6(2)^{\mathrm{b}}$ & $9.1(2)^{\mathrm{b}}$ & $3.2(0.3)^{\mathrm{a}}$ \\
\hline $\begin{array}{c}\text { p-value } \\
p \text {-vrijednost }\end{array}$ & 0.001 & 0.004 & 0.004 & 0.001 & 0.230 & 0.003 \\
\hline
\end{tabular}


Regardless of treatment, two variables were found to be significant for predicting the probability that an individual tree will be damaged: slope $(\mathrm{P}<0.05)$ and distance to skid trail $(\mathrm{P}<0.01)$. In order to assess the individual effects of the three treatments, each treatment was tasted as a base line against the other two. The second treatment was significantly different from first and second treatments $(\mathrm{P}<0.01)$. The ratios indicated that a tree is 2.6 times as likely to be damaged in second treatment (high harvest intensity) compared to first treatment. The final probability model resulted in three different intercept parameters (one for each treatment):

$\mathrm{B}_{01}=0.2333, \mathrm{~B}_{02}=0.9876, \mathrm{~B}_{03}=0.4312$

The final model is described as:

$$
P=\left[1+\exp \left(-\left(B_{0}+0.04(S L O P E)-0.05(D I S T)\right)\right)\right]^{-1}
$$

Where:

$P \quad$ probability of damages

SLOPE slope intercepts in skid trails

DIST distance of an individual stem to the nearest skid trail

Slope intercepts had a significant effect on the probability of damage regardless of treatment. In all treatments, as slope intercepts increased, the probability of damage increased, and as distance from skid trail increased, the probability of damage decreased. Overall, the probability of damage was higher in the second treatment, ranging from 52-88 $\%$ for slope intercepts and 35-77 \% for distance from skid trail. The probability of damage ranged from 22-72 \% for slope intercepts and 26-67\% for distance from skid trail, in the first and third treatment.

\section{Discussion and conclusions Rasprava i zaključci}

According to the results of the current research, in all treatments, $97 \%$ of scuff, scrape, and gouges occurred within the first $1.3 \mathrm{~m}$ of the bole (Nikooy 2007, Behjou 2014). Other studies have shown that wounds with $>100 \mathrm{~cm}^{2}$ of exposed sapwood are likely to develop decay (Hesterberg 1957, Lavallee and Lortie 1968). The frequency of overall damage for the second treatment in this study is higher than those reported in the literature for damage from felling in individual tree selection (2.4\%). In Caspian forests, Naghdi (2004) reported that $1.4 \%$ of residual trees per hectare $(\geq 10 \mathrm{~cm})$ received some type of wound, and $0.6 \%$ of residual trees had wood exposed wound. In another study, Nikooy et al. (2007) found that $1.9 \%$ of residual trees per hectare $(\geq 10 \mathrm{~cm})$ received some type of wound; the average pre-harvest stand density in those studies ranged from 160-170 trees per hectare, which is similar to stand density in the present study. These results are in good correlation with our study. Other studies in other countries using damage probability models found similar results regarding distance from skid trail (Nichols et al. 1994). Nichols et al. (1994) also reported that, as pre-harvest basal area increased, the probability of damage increased, and this result is somewhat similar with the results of the present study. In this study, stands were selected for uniformity in pre-harvest conditions. The second treatment also had the highest frequency and largest wounds from felling. In addition, total stand damage was positively correlated with residual trees per hectare (Holmes et al. 2002). Similar results were found in our study. Wounds of more than or equal to $100 \mathrm{~cm}^{2}$ are less likely to complete 10 years after felling compared to smaller wounds (Smith et al. 1994). Large wounds are also more likely to develop decay and some volume-degraded up to 20 years after injury (Hesterberg 1957, Lavallee and Lortie 1968). The second treatment in our study resulted in more damage to residual trees as the harvest intensity (marked trees per hectare) increased.

\section{Acknowledgement - Zahvala}

The author would like to thank Shafaroud Company in the North of Iran for allowing field data collection on their operations.

\section{References - Literatura}

Aho, P. E., Fiddler, G., Filip, G. M., 1983: How to reduce injuries to residual trees during stand management activities. USDA Forest Service, Gen. Tech. Rep. PNW- 156, 17 p.

Behjou, F. K., Majnounian, B., Namiranian, M., Dvorak, J., 2008: Time study and skidding capacity of the wheeled skidder Timberjack 450C in Caspian forests. Journal of Forest Science 54(4): 183-188. https://doi. org/10.17221/5/2008-JFS

Behjou, F. K., 2013: Economic analysis on log damage during logging operation in Caspian Forests. Journal of Forest Science 24(3): 585-589. https://doi.org/10.1007/ s11676-013-0344-y

Cline, M. L., Hoffman, B. J., Cyr, M., Bragg, W., 1991: Stand damage following whole-tree partial cutting in northern forests. Northern Journal of Applied Forestry 8(2): 72-76. 
Dvorak, J., 2005: Analysis of forest stand damages caused by the usage of harvester technologies in mountain areas. Electronic Journal of Polish Agricultural Universities 8(2): 1-9.

Fajvan, M., Knipling, A., Tift, B. D., 2002: Damage to Appalachian hardwoods from diameter-limit harvesting and shelter wood establishment cutting. Northern Journal of Applied Forestry 19(2): 80-87.

Hesterberg, G. A., 1957: Deterioration of sugar maple following logging damage. USDA Forest Service, Station Paper-51. St. Paul, MN, 58 p.

Holmes, T. P., Blat, G. M., Zweede, J. C., Pereira, R., Barreto, P., Boltz, F., Bauch, R., 2002: Financial and ecological indicators of reduced impact logging performance in the eastern Amazon. Forest Ecology and Management 163(2): 93-110. https://doi.org/10.1016/S0378-1127(01)00530-8

Jackson, S. M., Frederickson, T. S., Malcolm, J. R., 2002: Area disturbed and residual stand damage following logging in a Bolivian tropical forest. Forest Ecology and Management 166(3): 271-283. https://doi.org/10.1016/ S0378-1127(01)00681-8

Krueger, W., 2004: Effects of future crop tree flagging and skid trail planning on conventional diameter limit logging in a Bolivian tropical forest. Forest Ecology and Management 188(1): 381-393. https://doi.org/10.1016/j. foreco.2003.08.006

Lavallee, A., Lortie, M., 1968: Relationships between external features and trunk rot in living yellow birch. Forestry Chronicle 44(2): 5-10.

Limaei, S. M., Lohmander, P., 2007: Stumpage prices in the Iranian Caspian forests. Asian Journal of Plant Sciences 6(7): 1027-1036. https://doi.org/10.3923/ajps.2007.1027.1036

Marvimohajer, M. R., 2006: Silviculture. Tehran University press, $367 \mathrm{p}$.
Naghdi, R., 2004: Comparison between short-wood and long-wood harvesting method in Caspian Forests. PhD Thesis, $276 \mathrm{p}$.

Nichols, M. T., Lemin, R. C., Ostrofsky, W. D., 1994: The impact of two harvesting systems on residual stems in a partially cut stand of northern hardwoods. Canadian Journal Forest Research 24(2): 350-357. https://doi. org/10.1139/x94-047

Nikooy, M., 2007: Optimization of production costs and reducing logging damages in Caspian forests. PhD Thesis, Faculty of Natural Resources, University of Tehran, $214 \mathrm{p}$.

Nyland, R. D., Gabriel, W. J., 1971: Logging damage to partially cut hardwood stands in New York State. State Univ., Coll. Of For., Syracuse Univ., AFRI res. pap. 38 p.

Reisinger, T. W., Pope, P. E., 1991: Impact of timber harvesting on residual trees in a central hardwood forest in Indiana. Proceedings of $8^{\text {th }}$ Central Hardwood Forest Conference USDA Forest Service, Gen. Tech. Rep. NE-148, 82-91.

Shigo, A. L., 1985: Wounded forests, starving trees. Journal of Forestry 83(11): 668-673. https://doi.org/10.1093/ jof/83.11.668

Shigo, A. L., 1979: Tree decay-an expanded concept .USDA Forest Service Agric. Info. Bull. 419, 73 p.

Smith, H. C., Schuler, T. M., 1994: Closure of logging wounds after $10 \mathrm{yr}$. USDA Forest Service esearch Paper NE-692, 6 p.

Solgi, A., Najafi, A., 2007: Investigation of residual tree damage during ground-based skidding. Pakistan Journal of Biological Science, 10(10): 1755-1758. https://doi. org/10.3923/pjbs.2007.1755.1758 


\section{Sažetak}

\section{Oštećenja preostalih stabala nakon preborne sječe u kaspijskim šumama}

U radu se procjenjuju oštećenja preostalih stabala uzrokovanih pridobivanjem drva u kaspijskim bjelogoričnim sastojinama. Nakon sječe provedeno je terensko istraživanje radi prikupljanja podataka o svim preostalim stablima (vrste, prsni promjer, visina) te o oštećenjima stabala (veličina, mjesto, intenzitet oštećenja). Promatrani su različiti intenziteti sječe, a postupci su ponovljeni tri puta. Prema rezultatima sadašnjih istraživanja 97 \% ogrebotina, oguljotina i drugih oštećenja događa se na proa 1,3 m debla (Nikooy 2007, Behjou 2014). Druga su istraživanja pokazala da će otvorena oštećenja s > $100 \mathrm{~cm}^{2}$ izložene bjeljike vjerojatno izazvati trulež (Hesterberg 1957, Lavallee i Lortie 1968). Za kaspijske šume Naghdi (2004) izvještava da 1,4\% preostalih stabala po hektaru ( $\geq 10 \mathrm{~cm}$ ) zadobiva neku vrstu oštećenja, a na 0,6\% stabala drvo je izloženo oštećenju. Nikooy i dr. (2007) utvrdili su da je 1,9\% preostalih stabala po hektaru ( $\geq 10 \mathrm{~cm}$ ) zadobilo neku vrstu oštećenja, pri čemu se prosječna gustoća sastojina u tim istraživanjima kretala od 160 do 170 stabala po hektaru slično kao u ovom istraživanju. Istraživanja u drugim zemljama u kojima su primjenjivani modeli vjerojatnosti oštećivanja pokazala su slične rezultate s obzirom na udaljenost od traktorske vlake (Nichols $i d r .1994)$. Nichols $i$ dr. (1994) također su izvijestili da se porastom temeljnice sastojine povećava vjerojatnost oštećivanja, što je donekle slično rezultatima ovoga istraživanja. Dodatno, ukupno oštećivanje sastojine pozitivno korelira s brojem preostalih stabala po hektaru (Holmes $i$ dr. 2002). Slično se utvrdilo i ovim istraživanjem. Oštećenja veća od $100 \mathrm{~cm}^{2}$, u usporedbi s manjim ranama, manje će se vjerojatno zatvoriti 10 godina nakon sječe (Smith i dr. 1994). Velika oštećenja također imaju veću vjerojatnost za razvoj truleži, a ponegdje se njihov obujam pogoršava i do 20 godina nakon ozljede (Hesterberg 1957, Lavallee i Lortie 1968). Rezultati istraživanja prikazanih u radu pokazuju da postupci sa srednjim i visokim intenzitetom sječe uzrokuju najoiši postotak šteta te najveća oštećenja na stablima. Zaključuje se da bi intenzitet sječe trebao biti ograničen na 3 stabla/ha tijekom svake operacije pridobivanja drva kako bi se smanjio opseg oštećivanja stabala, a time i budući financijski gubici.

Ključne riječi: oštećivanje stabala, pridobivanje drva, kaspijske šume

Received (Primljeno): March 03, 2020.

Accepted (Prihvaćeno): June 23, 2020
Authors' addresses - Adrese autorâ:

Farshad Keivan Behjou University of Mohaghegh Ardabili Department of Agricultural Technology \& Natural Resources Ardabil IRAN

Alireza Ghomi Motazeh* e-address: alireza.ghomi@yahoo.com University of Guilan Department of Natural Resources Sowmesara IRAN

* Corresponding author - Glavni autor 
